\title{
Implication of Constructivism on Business English Textbook and Suggestions
}

\author{
Guoqing Zhang \\ No.1488, Buoshuo Road, Jingyue District, Changchun City, Jilin Province, China \\ 153266111@qq.com
}

Keywords: Constructivism; Business English textbook; Present situation; Suggestions

\begin{abstract}
As the most active branch of special-purpose English, business English plays an increasingly prominent role in foreign language teaching. Writing skills are the basic requirements for business professionals in modern business and play an important role in the cultivation of compound talents. It plays a role not only in helping business communication and but also in establishing normal business relations. However, there exist many potential problems in the construction of business English writing textbooks in China. This paper takes the construction of business English business English writing textbook as an example, studying how to break through the traditional mode of teaching material construction. Under the guidance of constructivism theory, combining with ability requirement in society, the paper focuses on the students' business English writing ability to achieve the goal of training students to adapt to the needs of society.
\end{abstract}

\section{Introduction}

With the frequent communication between China and the rest of the world, enterprises need a large number of talents with both international trade business knowledge and skills and solid language basic skills and intercultural communication. Business English writing ability has become an important bridge for international enterprises to communicate with each other, promote business development, conduct transactions and establish friendly cooperative relations. As one of the important ways to communicate effectively in e-commerce, business English writing ability plays a very important role in international trade. Persuasive email and good communication are effective lubricants that help overcome cultural barriers. The author took the enterprises and business English majors in Jilin Province as the research object, through questionnaire investigation and interview investigation, and found that there is a gap between business English writing textbooks and the requirements of talents in enterprises. In order to improve students' practical ability, this paper, guided by the actual needs of talents in the business field, analyzes the current situation of business English writing textbooks and puts forward suggestions for reform.

\section{ESP teaching and Constructivism Theory}

The Characteristics of ESP Teaching. ESP has been used in English teaching since the 1960s. According to Dudley Evans and St. John, ESP is the English teaching for Specific Purposes. It involves not only language and linguistic knowledge, but also other knowledge with the purpose of cultivating and improving students' ability to use English in professional fields. [1] Therefore, the majors studied by students are divided into business English, financial English and legal English, etc. The ESP curriculum system covers three aspects: "English language level + professional operation skills + professional subject knowledge". There are four absolute characteristics and two variable characteristics. The four absolute characteristics are: The curriculum must meet the special requirements of learners; The course must be relevant in its content (subject and topic) to certain subjects, occupations, and activities; The emphasis should be placed on the language application that tries to adapt grammar, vocabulary and discourse structure to those specific activities; Purposes must be in sharp contrast to English for General Purposes. The two variable characteristics are: It can be limited to the cultivation of a language skill; Teaching can be conducted according to any teaching method. Business English writing course, as a backbone of ESP business English course, 
contains common professional English vocabulary, syntax structure and expression, etc., and its textbook design learn from Peter Stevens for the characteristics of ESP teaching, from the demand of positions in enterprises. [2]

Constructivism Theory. Constructivism rises in the 1980s. It believes that learning is always connected with a certain social cultural background of the associated "situation". Learning in the actual situation can make the learners use the original knowledge to assimilate new knowledge and give the new knowledge a certain meaning. Constructivism emphasizes the three elements of "student-centered": To make the students give full play to the initiative in the learning process; make the students use the knowledge in different situations; to make the students form the understanding of objective things and the ability to solve practical problems with the feedback from their own action.[3]

Every link of practice teaching through the teaching design, like creating vivid simulation close to the actual business activities, can effectively stimulate the imagination, enable learners to use their original cognitive structure of knowledge and experience to assimilate the new knowledge and give the new knowledge a new meaning. [4]

\section{Analysis of Current Situation of Business English Writing Textbooks}

The business English writing is a course combines business knowledge and English skills. With a specific purpose, the course aims mainly to cultivate learner's ability of English application in the work environment. But the problems that students often reflect in the course of business English writing are that the students know less about the language communication, lack professional knowledge, practical experience and understanding of business English language features. They only deal with problems arising from the business with their language skills and the strategies learned in tradition textbooks. As a result, students are bored with the course and lack interest. According to the characteristics of the course and the problems of students, there must be business communication activities in the teaching based on the target context. To carry out these activities, teachers need to provide sufficient information and students can be encouraged to collect relevant information. The process of collecting materials by students is the process of learning real language materials and the process of cultivating their abilities. Such targeted activities are more likely to motivate students.

There are Defects in the Focus of the Traditional Business English Writing Textbook. The traditional business English writing textbook focuses more on the presentation of business process, that is, the content structure of the textbook is designed according to the order of business process. However, users of such textbooks often lack business experience. With the development of social needs, business English writing is no longer a single foreign trade letter and telegram. With the development of social needs, business English writing has become more and more practice-oriented which meet the needs of the society. In addition, other genres such as conference material writing, chart making, questionnaire survey, product manuals, etc. are not included in some textbooks. The textbooks which contains the above genres are often written in short form, which cannot help students to master these contents well.

There is the Lack of Preliminary Demand Analysis in Textbook Compilation. The lack of demand analysis will directly lead to the mismatch between the content of the textbook and its actual application, which will not allow students to learn practical writing content. One of the reasons is that the writers of business English writing are often engaged in teaching for a long time, and they don't have much chance to contact the real business world. In addition, the real text involves the company's trade secrets, which are often not available to the writer.

The Material of Business English Writing Textbook is not Authentic Enough. As an English for specific purpose, the most important feature of business English writing is its authenticity. However, it is difficult to find the real language materials in the compilation of business English writing textbooks in China. Business English has strong timeliness and authenticity, which is hard to guarantee in some dog textbooks on the market. Most of the materials in the textbooks do not come from the real business environment. Some editors only use the material found on the Internet. 
With no authentic material, no real business environment, it is hard for the business English writing learners to have strong interest and it difficult to help the students develop real business writing ability. [6]

The overall design of business English writing textbooks should focus on cultivating practical business talents, with the core of cultivating business English application ability. According to the professional standards and the actual needs of the working process of foreign secretaries, foreign trade salesmen, foreign trade salesmen and other posts, the course should take real project tasks as the carrier, adhering to the principle of combining knowledge with skills.

According to the requirement of business English writing for business English majors, the survey covers the following aspects: Does the content of college business English writing textbook cover the knowledge needed now? Whether the corpus of business English writing textbooks is authentic? Whether the business English writing teaching material can satisfy the actual needs of the sentence patterns and vocabulary? Whether business English writing is of great help to meet the work requirement? Is business English writing teaching material helpful in obtaining business English certificate? The following is the result of the survey.

Table 1 The results of the survey

\begin{tabular}{|l|l|l|l|}
\hline & Not satisfied & satisfied & Quite satisfied \\
\hline $\begin{array}{l}\text { 1. Does the content of college business English writing } \\
\text { textbook cover the knowledge needed in workplace? }\end{array}$ & $66 \%$ & $30 \%$ & $4 \%$ \\
\hline $\begin{array}{l}\text { 2. Whether the corpus of business English writing } \\
\text { textbooks are authentic? }\end{array}$ & $63 \%$ & $28 \%$ & $7 \%$ \\
\hline $\begin{array}{l}\text { 3. Whether the business English writing teaching } \\
\text { material can satisfy the actual needs of the sentence } \\
\text { patterns and vocabulary? }\end{array}$ & $24 \%$ & $53 \%$ & $23 \%$ \\
\hline $\begin{array}{l}\text { 4. Whether business English writing is of great help to } \\
\text { meet the work requirement? }\end{array}$ & $47 \%$ & $35 \%$ & $18 \%$ \\
\hline $\begin{array}{l}\text { 5. Is business English writing teaching material helpful } \\
\text { in obtaining business English certificate? }\end{array}$ & $48 \%$ & $36 \%$ & $26 \%$ \\
\hline
\end{tabular}

\section{Suggestions on Revision of Business English Writing Textbooks}

Modern foreign enterprises require graduates to focus on "doing" and "acting". That is, apply technical knowledge to business field or real life, solve practical problems of business writing and provide high quality business services. The acquisition of English skills is of great importance to students. However, in order to cultivate high-quality business English talents to adapt to the modern society, the requirement of basic English language ability cannot be overlooked. At the same time, only by learning business practice and business ethics can the construction of business English writing courses meet the needs of the development of English skills and social progress. The goal of the course should be to focus on English skills training and to combine English skills training with business ethics training, so as to guide students to establish correct business professional values. Therefore, the goal of business English writing should be divided into knowledge target, ability target and quality target. Targets of knowledge include writing all kinds of English documents, contracts, correspondence and telecommunications according to the scope of activities and responsibilities of his/her position. The ability target mainly involves understanding and grasping the corresponding format, the content and the writing characteristics. The quality goal is the comprehensive quality of communication, cooperation, competition and analysis.

The Course should be "Task-oriented" to Stimulate Students' Interest in Learning. When compiling textbooks, the guiding ideology should be to "accomplish tasks". When the guiding ideology of the textbook is clear, the teacher will have a specific target when teaching, thus leading to clear thinking and good teaching effect. [7] 
Build Business English Writing Corpus, Audio-visual and Multimedia Learning system, the Network Teaching Resources, Online Dictionary Through the Internet. Set up interactive platform to satisfy the students' needs of individualized and autonomous learning and realize the integration of teaching, learning and acting.

The Selection of Teaching Materials Should be Based on Vocational Needs. The textbook should pay attention to the basic skills of language and pay attention to the balance between practicality and humanity. The textbook should cover many aspects of the needs of the contemporary workplace, such as advertising, exhibition, finance, fashion, entrepreneurship, and study abroad. The lack of real business activities in business English teaching and the insufficient integration of business activities and English teaching have always been a difficult problem for teachers. Textbooks for teaching business English writing, therefore, should include a large number of real and vivid material, so that students could master the language skills and understand business English writing in the practical work to improve the ability of adapting to the position. The textbook should contain a large number of cases as the teaching content, the real business communication situations as reference and combine the English language skills and business situation closely together.

Systematic and Comprehensive Exercises Should be Designed to Improve the Students' Communicative Competence in English. Students' communicative competence plays an important role in the construction of business English courses. At present, most textbooks only pay attention to the teaching of basic English knowledge, but neglect the cultivation of communicative competence in English. The talents cultivated in this way are lack of communication skills and cannot meet the needs of the workplace.

The Textbook Should be Designed with Diversified Teaching Activities. Create the cooperative learning mode of "learning while doing" to improve the learning effect. Cooperative learning is one of the task-based teaching model. Its characteristic is to divide the students into groups to complete a particular task, help each other, do mutual communication and cooperation in order to obtain English basic knowledge and skills needed in the workplace. When students study in groups, the smaller the group, the better, so that every student can participate in specific tasks. The teacher only indirectly guides the students to study randomly. This allows the students more freedom in doing activities. If the idea of textbook design is not task-based teaching, then cooperative learning model can not be realized. Without cooperative learning in groups or teams, it hard to cultivate the students' interest in learning. Without initiative and interest, the learning effect of students cannot be guaranteed.

\section{Conclusion}

As a combination of international business knowledge and English language expression, business English writing is a comprehensive output process of language knowledge, application skills, learning strategies and cross-cultural communication skills. It directly reflects students' comprehensive application ability to language, professional knowledge and cultural literacy. Under the guidance of constructivism theory, the introduction of real business English writing materials in business English writing teaching material reform enables learners to experience the business situation and the use of language, which can improve the learners' interest and activate the students in the classroom. This will improve the learner's knowledge and language application ability.

\section{References}

[1]Hutchinson, T. \& A. Waters. 1987. English for Specific Purposes: A learning-centered approach. Cambridge: Cambridge University Press.

[2] Eric.ed.gov, Dudley-Evans, Tony. An Overview of ESP in the 1990s. In: The Japan Conference on English for Specific Purposes Proceedings (Aizuwakamatsu City, Fukushima, Japan, November 8, 1997) 
[3] Taber, K. S. (2011). Constructivism as educational theory: Contingency in learning, and optimally guided instruction. In J. Hassaskhah (Ed.), Educational Theory (pp. 39 - 61).

[4] Durmus, Y. T. (2016). Effective Learning Environment Characteristics as a requirement of Constructivist Curricula: Teachers' Needs and School Principals' Views . International Journal of Instruction, 9(2)

[5] Professional Writing.Purdue University College of Liberal Arts. Retrieved November 7, 2014.

[6] https://en.wikipedia.org/wiki/Professional_writing

[7] Peng L, Fang W. Heterogeneity of Inferring Reputation of Cooperative Behaviors for the Prisoners' Dilemma Game [J]. Physica A: Statistical Mechanics and its Applications, 2015, 433: 367-378. 